\title{
La représentation du père Brown et du mal dans les nouvelles policières de G. K. Chesterton : The Innocence of Father Brown (1911), entre orthodoxie et hétérodoxie
}

The Representation of Father Brown and Evil in G.K. Chesterton's Detective Stories: The Innocence of Father Brown (1911), Between Orthodoxy and Heterodoxy

Françoise Dupeyron-Lafay

\section{(2) OpenEdition}

Journals

Édition électronique

URL : http://journals.openedition.org/rfcb/3659

DOI : 10.4000/rfcb.3659

ISSN : 2429-4373

Éditeur

CRECIB - Centre de recherche et d'études en civilisation britannique

Édition imprimée

Date de publication : 1 mars 2013

ISBN : 2-911580-37-0

ISSN : 0248-9015

\section{Référence électronique}

Françoise Dupeyron-Lafay, « La représentation du père Brown et du mal dans les nouvelles policières de G. K. Chesterton: The Innocence of Father Brown (1911), entre orthodoxie et hétérodoxie », Revue Française de Civilisation Britannique [En ligne], XVIII-1 | 2013, mis en ligne le 01 mars 2013, consulté le 19 mars 2020. URL : http://journals.openedition.org/rfcb/3659 ; DOI : https://doi.org/10.4000/rfcb. 3659

Ce document a été généré automatiquement le 19 mars 2020

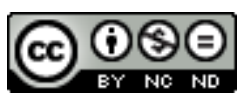

Revue française de civilisation britannique est mis à disposition selon les termes de la licence Creative Commons Attribution - Pas d'Utilisation Commerciale - Pas de Modification 4.0 International. 


\title{
La représentation du père Brown et $\mathrm{du}$ mal dans les nouvelles policières de G. K. Chesterton : The Innocence of Father Brown (1911), entre orthodoxie et hétérodoxie
}

\author{
The Representation of Father Brown and Evil in G.K. Chesterton's Detective \\ Stories: The Innocence of Father Brown (1911), Between Orthodoxy and \\ Heterodoxy
}

Françoise Dupeyron-Lafay

1 Évoquer la nature «orthodoxe » ou «hétérodoxe » de la pensée et de l'œuvre (de détection) de G. K. Chesterton implique une approche du domaine religieux, mais ces deux adjectifs possèdent aussi une acception plus large, relative à des comportements et à une idéologie conformistes ou excentriques par rapport à la doxa dominante. Chesterton lui-même emploie le premier terme dans cette acception dès la première nouvelle (sur 12) des Father Brown Stories, 'The Blue Cross' (1910)' , où il est question d'un sucrier peu « orthodoxe ». En effet, contre toute attente, on y trouve du sel, la salière contenant pour sa part du sucre. Cette facétie, cette excentricité du quotidien donnent d'emblée la mesure de l'ambiance du recueil The Innocence of Father Brown'2.

2 Le père Brown est en quelque sorte le "sel dans le sucrier» ou le "sucre dans la salière » de la littérature policière, car le choix d'un prêtre catholique (d'apparence un peu ridicule et insignifiante) dans le rôle du détective (certes amateur) aux prises avec le crime, n'a rien d'" orthodoxe ", surtout si on le compare à ses prédécesseurs du XIX ${ }^{\mathrm{e}}$ siècle dotés d'une stature plus héroïque, notamment au grand Sherlock Holmes. Chesterton, amateur de fiction policière ${ }^{3}$, connaissait parfaitement les maitres du genre, qu'il cite de manière plus ou moins explicite dans ses textes. Son détective 
atypique n'est donc pas une erreur de débutant, mais une stratégie délibérée employée dans cinq recueils pendant plus de vingt ans.

\section{La représentation « hétérodoxe » du père Brown}

3 La présence d'un prêtre est donc, de fait, « hétérodoxe ", mais ce qui l'est encore plus est la manière dont il est représenté. Lors de sa première apparition dans 'The Blue Cross', le récit donne une image pitoyable de ce père Brown, dont le lecteur ignore encore qu'il s'agit d'un détective amateur hors pair, d'une intelligence et d'une sagacité exceptionnelles. Tout ce que nous voyons dans l'immédiat (ou, plus exactement, tout ce que nous fait voir le policier Valentin, chef de la police parisienne et enquêteur de renommée internationale, puisque le récit adopte en quelque sorte au style indirect libre sa perspective anticléricale) est un petit prêtre catholique originaire d'un obscur village de l'Essex, d'apparence miteuse, niaise et vulnérable, l'innocent que semble évoquer le titre du recueil :

Valentin gave it up and almost laughed. The little priest was so much the essence of those Eastern flats; he had a face as round and dull as a Norfolk dumpling; he had eyes as empty as the North Sea [...] The Eucharistic Congress had doubtless sucked out of their local stagnation many such creatures, blind and helpless, like moles disinterred [...] He had a large, shabby umbrella, which constantly fell on the floor. He did not seem to know which was the right end of his return ticket. He explained with a moon-calf simplicity to everybody in the carriage that he had to be careful, because he had something made of real silver "with blue stones" in one of his brown-paper parcels. ${ }^{4}$

4 Le portrait n'est pas plus flatteur dans 'The Invisible Man', où le père Brown apparaît initialement comme un objet incongru, échoué par hasard dans le bric-à-brac de l'appartement de Flambeau, voleur de son état: 'The ornaments were sabres, harquebuses, Eastern curiosities, flasks of Italian wine, savage cooking-pots, a plumy Persian cat, and a small dusty-looking Roman Catholic priest, who looked particularly out of place. ${ }^{5}$ Le prêtre est ensuite comparé à un meuble, puis à divers animaux, par exemple quand il regarde le sol de l'air inexpressif d'un poisson. Mais les rôles seront très bientôt inversés : le " petit chien docile » qui suivait Angus et Flambeau en silence ('They turned out into the street, the small priest trundling after them with the docility of a small dog' 6 ) devient sous peu le guide (au sens propre et au sens figuré) des deux hommes, qui le suivront pour découvrir la vérité : 'Unconsciously they were walking with quickening steps down the long sweep of road [...] Father Brown leading briskly, though in silence'. . C'est précisément, pour reprendre ses termes, parce qu'il est lui-même "mentalement invisible ${ }^{8}$ qu'il $^{\prime}$ comprend que Welkin, lui-même un "homme invisible" (du fait de son statut subalterne en tant que facteur), a pu s'introduire chez Isidore Smythe et l'assassiner.

Ironie du sort, cet être à première vue inintéressant et négligeable, l'adjectif 'little' résumant son insignifiance, finit toujours par révéler à quel point les apparences sont trompeuses, et par susciter admiration et respect. Ainsi, Valentin et le voleur Flambeau s'inclinent devant lui en signe d'hommage à la fin de 'The Blue Cross'.

\section{Le père John 0' Connor, inspirateur}

6 Ce Father Brown est inspiré d'un homme bien réel, le père John O'Connor, que Chesterton connaissait depuis 1904, et qui était devenu son conseiller spirituel, comme 
en témoigne l'hommage rendu dans la dédicace du recueil de 1927, The Secret of Father Brown: 'To Father John O' Connor, of St Cuthbert's Bradford, whose truth is stranger than fiction, with a gratitude greater than the world'. Max Ribstein précise que Chesterton l'avait rencontré à Keighley (région de West Riding, Yorkshire) « fortuitement à l'occasion d'une tournée de conférences dans le nord de l'Angleterre ", et qu'il "organisera la confession et la réception de son ami dans le sein de l'Église catholique le 30 juillet $1922 .{ }^{10} \mathrm{M}$. Ribstein insiste sur le rôle de J. O'Connor : "l'inspirateur, mais non le calque » du père Brown. Au chapitre XVI ('The God with the Golden Key') de son autobiographie de 1936, The Autobiography of G. K. Chesterton, l'auteur explique bien dans quelle mesure le père Brown constitue une version personnelle et "romancée » de son ami et confesseur, qu'il décrit en termes nettement plus flatteurs: 'A small man with a smooth face and a demure but elfish expression', et dont il souligne avec force le tact, le sens de l'humour, et la manière dont celui-ci avait su gagner l'estime et la confiance des villageois un peu frustes du Yorkshire, bien qu'il fût catholique et que ces derniers fussent majoritairement protestants ${ }^{11}$ :

In Father Brown, it was the chief feature to be featureless [...] his conspicuous quality was not being conspicuous. His commonplace exterior was meant to contrast with his unsuspected vigilance and intelligence; and that being so, of course I made his appearance shabby and shapeless, his face round and expressionless, his manners clumsy, and so on. At the same time, I did take some of his inner intellectual qualities from my friend, Father John O'Connor of Bradford, who [...] is not shabby, but rather neat; he is not clumsy, but very delicate and dexterous [...] He is a sensitive and quick-witted Irishman [...] My Father Brown was deliberately described as a Suffolk dumpling from East Anglia [...] But for all that, there is a very real sense in which Father $\mathrm{O}^{\prime}$ Connor was the intellectual inspiration of these stories. ${ }^{12}$

\section{Vide et plénitude : orthodoxie et principes apostoliques}

7 Chesterton était donc pleinement conscient d'avoir pris des libertés, «malmené » son modèle, et créé une figure de prêtre à certains égards peu orthodoxe, peu conforme à la dignité attendue d'un personnage d'ecclésiastique, et peu apte à inspirer le respect. Le père Brown fait ainsi figure de pierre précieuse cachée par une gangue disgracieuse, exprimée par les couleurs ternes qui lui sont associées : le gris de ses yeux, le brun de son nom si passe-partout et si banal. Christiane d'Haussy, dans La Vision du monde chez G. K. Chesterton, évoque « cette idée, familière à Chesterton, on le sait, d'un moi réduit à l'extrême pour mieux percevoir le monde extérieur $\aleph^{13}$, forme d'ascèse mentale qu'exprime fréquemment l'image du regard "vide" du prêtre, pris à tort pour un signe d'imbécillité : 'He had eyes as empty as the North Sea' (BC) et 'Colonel Pound looked at him keenly, but the speaker's mild grey eyes were fixed upon the ceiling with almost empty wistfulness ${ }^{14}$. On notera bien d'ailleurs la contradiction entre ces yeux vides et la référence à la mer, espace vaste qui évoque non l'absence, mais une forme d'infini sublime.

8 Chesterton écrivait à la fin du chapitre XVI de son autobiographie: 'But I know that he who is called Pontifex, the Builder of the Bridge, is called also Claviger, the Bearer of the Key; and that such keys were given him to bind and loose when he was a poor fisher in a far province, beside a small and almost secret sea. ${ }^{15}$ Et l'on peut dire que le symbolisme de la pêche et 
des pêcheurs présent dans 'The Queer Feet' préfigure ce passage de l'autobiographie. Cette nouvelle se déroule pendant le dîner du club des Twelve True Fishermen, version ironique des douze apôtres, les douze «pêcheurs » du club, préoccupés par la richesse et le pouvoir, constituant l'antithèse des principes apostoliques. Le lien avec la pêche réside simplement dans le menu de leur dîner, à base de poisson. Tout ce qui leur importe est de retrouver les couverts d'argent que Flambeau leur a dérobés; en revanche, la façon dont le père Brown présente sa mission de sauveur et de pêcheur d'âmes a tout d'une allégorie chrétienne :

'Odd, isn't it,' he said, 'that a thief and a vagabond should repent, when so many who are rich and secure remain hard and frivolous [...] there are your knives and forks. You are The Twelve True Fishers, and there are all your silver fish. But He has made me a fisher of men.'

'Did you catch this man?' asked the colonel, frowning.

Father Brown looked him full in his frowning face. 'Yes,' he said, 'I caught him, with an unseen hook and an invisible line which is long enough to let him wander to the ends of the world, and still to bring him back with a twitch upon the thread."16

C. d'Haussy précise que la vision du monde de l'auteur est «fortement colorée par sa conception du bien et du mal jugés dans une perspective chrétienne très orthodoxe. $»^{17} \mathrm{Et} \mathrm{si}$ l'apparence du père Brown n'est pas orthodoxe, son comportement, ses opinions religieuses et sa conception de l'existence le sont généralement ${ }^{18}$, mais pas toujours, ce qui doit être souligné :

Father Brown's figure remained quite dark and still; but in that instant he had lost his head. His head was always most valuable when he had lost it. In such moments he put two and two together and made four million. Often the Catholic Church (which is wedded to common sense) did not approve of it. Often he did not approve of it himself. But it was real inspiration - important at rare crises - when whosoever shall lose his head the same shall save it. ${ }^{19}$

\section{Le père Brown, confesseur et sauveur d'âmes}

10 Il est par ailleurs fier (péché véniel ?) de son rôle de garde-fou moral : 'He had averted a crime and, perhaps, saved a soul, merely by listening to a few footsteps in a passage. He is perhaps a little proud of this wild and wonderful guess of his, and it is possible that he might refer to it. ${ }^{20} \mathrm{Il}$ a en effet réussi à convertir Flambeau, le "colosse du crime » décrit au début de 'The Blue Cross'. Ce dernier, ancien criminel (français) ${ }^{21}$, voleur récidiviste de bijoux précieux et d'argenterie dans les quatre premières histoires (notamment $\mathrm{BC}, \mathrm{QF}$ et FS), devient l'ami du père Brown, qui finit par le sauver à la fin de 'The Flying Stars' en l'exhortant à restituer les rubis qu'il a volés et en lui déclarant, dans une langue très convaincante et imagée, reposant sur un paradoxe ('honest outlaw') et sur une allégorie (l'arbre dans lequel Flambeau a trouvé refuge, mais dont le symbolisme chrétien est clair) :

'I want you to give up this life. There is still youth and honour and humour in you; don't fancy they will last [...] Many a man I've known started like you to be an honest outlaw, a merry robber of the rich, and ended stamped into slime [...] I know the woods look very free behind you, Flambeau; I know that in a flash you could melt into them like a monkey. But some day you will be an old grey monkey, Flambeau. You will sit up in your free forest cold at heart and close to death, and the tree-tops will be very bare'. ${ }^{22}$

11 Nous découvrons ensuite Flambeau en détective dans 'The Invisible Man' (nouvelle 5), du côté des forces du bien et de la justice, un peu à la façon de Vidocq, truand repenti... 
Grâce au prêtre, il est (re)devenu un enfant, et l'on notera que les termes 'child', 'little boy', 'childish' sont d'ailleurs souvent associés au père Brown, et possèdent toujours un sens très positif qui rappelle la valorisation des êtres simples et innocents dans les É vangiles : "You must tell us all about it," said Flambeau with a strange heavy simplicity, like a child. ${ }^{23}$ Le père Brown joue fréquemment le rôle de "pêcheur » d'âmes en perdition, et de confesseur, mais cela, toujours à notre insu. Le lecteur n'apprend jamais explicitement ce que Flambeau ou Welkin, le meurtrier d'Isidore Smythe, ont révélé au prêtre, en conformité avec le secret de la confession :

'What did you do to him?' cried the colonel, with unusual intensity. 'What did he tell you?'

'I beg your pardon,' said the priest immovably, 'that is where the story ends. ${ }^{24}$ But Father Brown walked those snow-covered hills under the stars for many hours with a murderer, and what they said to each other will never be known. ${ }^{25}$

\section{Une hétérodoxie insidieuse}

Il se dessine cependant une forme d'hétérodoxie assez imperceptible et insidieuse dans les Father Brown Stories. Elle ne découle pas intrinsèquement de la conception religieuse de Chesterton, mais plutôt de sa mise en œuvre littéraire, qui semble échapper en partie au contrôle de la raison ${ }^{26}$, et qui a parfois tendance à gommer les frontières entre le bien et le $\mathrm{mal}^{27}$. La polarité morale n'est pas toujours aussi tranchée que l'on pourrait s'y attendre non seulement dans de la fiction policière, mais en outre dans de la fiction policière à caractère théologique; tout peut aisément basculer d'un côté comme de l'autre. Il faut rappeler que Valentin, policier dans 'The Blue Cross', devient meurtrier et se suicide dans la nouvelle suivante, 'The Secret Garden'; que Flambeau demeure estimable malgré tous ses méfaits, et que, d'une manière générale, ni le père Brown, ni le lecteur n'éprouve de réelle antipathie ou de sentiment de rejet envers les meurtriers Welkin (IM) ou Wilfrid Bohun (HG). On notera d'ailleurs que le prêtre, qui, seul, connaît la culpabilité de Bohun, décide de ne pas le dénoncer, bien qu'il ait assassiné son frère (impie et débauché) ${ }^{28}$. Le marteau (de forgeron) que, depuis le clocher de l'église, il a lancé sur ce frère honni est d'ailleurs décrit d'une façon très surprenante et ambiguë ; la comparaison avec la foudre de Dieu semble faire de ce meurtre un châtiment juste et mérité, et implicitement, presque le légitimer :

'I know what you did - at least, I can guess the great part of it. When you left your brother you were racked with no unrighteous rage, to the extent even that you snatched up a small hammer, half inclined to kill him with his foulness on his mouth. Recoiling, you thrust it under your buttoned coat instead, and rushed into the church [...] you could see the colonel's Eastern hat like the back of a green beetle crawling about. Then something snapped in your soul, and you let God's thunderbolt fall. ${ }^{29}$

13 Par ailleurs, le style et l'écriture de Chesterton ont tendance à esthétiser la noirceur et le mal, et à leur conférer une beauté et un pouvoir de fascination insoupçonnés. L'ouverture de 'The Flying Stars' nous fait entendre Flambeau, à présent réformé, se remémorant (non sans fierté) son passé criminel "artistique ", écho possible du titre provocateur de l'essai de Thomas De Quincey intitulé 'On Murder Considered as One of the Fine Arts' (1827) :

'The most beautiful crime I ever committed,' Flambeau would say in his highly moral old age, 'was also, by a singular coincidence, my last. It was committed at Christmas. As an artist I had always attempted to provide crimes suitable to the 
special season or landscapes in which I found myself, choosing this or that terrace or garden for a catastrophe, as if for a statuary group'. ${ }^{30}$

\section{L'esthétisation du mal} crime et création :

'A crime,' he said slowly, 'is like any other work of art. Don't look surprised; crimes are by no means the only works of art that come from an infernal workshop. But every work of art, divine or diabolic, has one indispensable mark - I mean, that the centre of it is simple, however much the fulfilment may be complicated. ${ }^{31}$

Le prêtre a beau souligner l'origine diabolique de « l'œuvre d'art ", les descriptions ${ }^{32} \mathrm{du}$ mal et de la délinquance allient le sublime et son envers : l'abjection et l'horreur. Mais par-delà cette noirceur, ce qui domine est le sentiment d'une insolite et inquiétante beauté, toute en paradoxes, comme la nature humaine : 'The glory of heaven deepened and darkened around the sublime vulgarity of man' ${ }^{33}$; 'man is himself a miracle, with his strange and wicked and yet half-heroic heart ${ }^{\prime 34}$. Les hauteurs sublimes du ciel et les profondeurs de l'abîme se rejoignent également dans la représentation des corps mutilés des victimes, avec les images à la fois terrifiantes et belles - fort éloignées des représentations orthodoxes et attendues du mal - de l'étoile ensanglantée, ou du sang qui coule dans l'eau, pareil au ciel empourpré au couchant: 'But the skull was only a hideous splash, like a star of blackness and blood'35; 'As by some weird whim of diabolical arabesque, blood was eddying out, very slowly, into the luminous water in snaky rings, like the transparent crimson of sunset clouds' ${ }^{36}$. C'est en cela que réside l'hétérodoxie (morale) de l'esthétique " chestertonienne », qui métamorphose et déréalise le "réel». Au creuset de cette écriture ornée et complexe, le réel devient un objet esthétique et un spectacle, ce qui implique un détachement et une distanciation (éthiques) ${ }^{37}$ :

[...] when a knock sounded at the double front doors. The priest opened them, and they showed again the front garden of evergreens, monkey-tree and all, now gathering gloom against a gorgeous violet sunset. The scene thus framed was so coloured and quaint, like a back scene in a play, that they forgot a moment the insignificant figure standing in the door. ${ }^{38}$

Il est en outre souvent malaisé de savoir qui pense, qui voit, ou de qui émane la voix narrative. Quand le ciel, au crépuscule, est comparé à des pierres précieuses, s'agit-il d'une projection mentale de la vision (immorale) de Flambeau, désireux de s'approprier les saphirs de la "croix bleue» (dans BC) ou les «étoiles volantes» (des rubis) dans 'The Flying Stars' ? De celle du père Brown, qui, émerveillé devant la beauté du monde, compare les étoiles à des saphirs et à des diamants (BC) ? Du point de vue de l'auteur lui-même? Il est impossible de trancher, et l'on voit bien combien l'autorité (et la responsabilité) narratives (et morales) sont insaisissables.

The gorgeous green and gold still clung to the darkening horizon; but the dome above was turning slowly from peacock-green to peacock-blue, and the stars detached themselves more and more like solid jewels. ${ }^{39}$

The winter afternoon was reddening towards evening, and already a ruby light was rolled over the bloomless beds, filling them, as it were, with the ghosts of the dead roses. ${ }^{40}$ 


\section{Retour à l'orthodoxie?}

Les originalités stylistiques peuvent cependant servir une cause plus orthodoxe, même quand elles donnent au "réel» (fictionnel) un aspect fantastique et onirique; la syntaxe peut, par exemple, suggérer les "méfaits du mal diffus dans l'univers $»^{41}$ en animant l'inanimé et en gommant le statut d'agent actif des êtres humains : 'The long roads of the North London suburbs seemed to shoot out into length after length like an infernal telescope [...] the winter twilight was already threatening the road ahead of them ${ }^{\prime 42}$. Les effets optiques déroutants (réduction, grossissement ou anamorphoses) induits par l'écriture véhiculent également un message éthique clair, quoique implicite. Cette technique de brouillage de nos repères habituels - visuels et moraux - est brillamment illustrée par la description du vertige et de la confusion que l'on éprouve en regardant le monde depuis le clocher de l'église gothique de 'The Hammer of God' :

The lines of the Gothic building plunged outwards into the void with a sickening swiftness akin to suicide [...] This church was hewn out of ancient and silent stone [...] And yet, when they saw it from below, it sprang like a fountain at the stars; and when they saw it, as now, from above, it poured like a cataract into a voiceless pit. For these two men on the tower were left alone with the most terrible aspect of Gothic; the monstrous foreshortening and disproportion, the dizzy perspectives, the glimpses of great things small and small things great; a topsy-turvydom of stone in the mid-air. Details of stone, enormous by their proximity, were relieved against a pattern of fields and farms, pygmy in their distance. ${ }^{43}$

Surplomber le monde et les hommes depuis ce gigantesque piédestal fait perdre le sens des proportions, y compris les siennes, comme l'a bien compris le prêtre quand il décrit la métamorphose psychologique de Wilfrid Bohun (le meurtrier) en termes spatiaux symboliques :

'I knew a man,' he said, 'who began by worshipping with others before the altar, but who grew fond of high and lonely places to pray from [...] in the belfry or the spire. And once in one of those dizzy places, where the whole world seemed to turn under him like a wheel, his brain turned also, and he fancied he was God. So that, though he was a good man, he committed a great crime.'

[...] 'He would never have had such a thought if he had been kneeling with other men upon a floor. But he saw all men walking about like insects. ${ }^{\prime 4}$

Les images optiques qui jalonnent le recueil démontrent donc les pouvoirs déformants du regard humain capable de naniser, de réifier, de déshumaniser les êtres, de ne plus voir en eux que des insectes (image récurrente du corpus) ou des pantins, ce qui est une façon de légitimer leur destruction. Dans 'The Blue Cross', Flambeau profère une menace horrible quand il lance au père Brown: 'Just hand over that sapphire cross of yours, will you? We're all alone here, and I could pull you to pieces like a straw doll.' ${ }^{45}$

Cette (dé)figuration que par cupidité, ou par orgueil, depuis les « hauteurs » (littérales pour Bohun, ou plus métaphoriques), certains humains font subir à autrui aboutit à une vision anamorphique du monde. Nous ne sommes en mesure de voir l'image corrigée que si nous nous plaçons au bon endroit et que nous possédons la surface réfléchissante convexe adaptée. C'est généralement le père Brown qui joue le rôle de cette surface correctrice. Mais il sait qu'il n'est lui-même pas exempt du mal inhérent qui habite l'être humain. Quand Wilfred Bohun (le coupable démasqué) s'exclame: 'How do you know all this? [...] Are you a devil?', le père Brown lui répond d'un ton grave : 'I am a man [...] and therefore have all devils in my heart. ${ }^{36}$ Cette perspicacité qui passe pour diabolique 
vient aussi de sa connaissance des bas-fonds et de la pègre (inspirée de celle du père 0 'Connor), qu'il évoque à la fin de 'The Blue Cross' ${ }^{47}$.

21 Chesterton se savait lui aussi ange et bête, ange et démon, dualité terrifiante avec laquelle il ne pouvait se réconcilier, mais qui l'obsédait et le fascinait obscurément. C'est ce qui explique l'ambiguïté tonale et idéologique des Father Brown Stories, et leur hésitation troublante aux frontières de l'orthodoxie et de l'hétérodoxie. La manière dont le père Brown (qui acquiert par moments le statut de double de l'auteur) s'identifie à certains criminels (particulièrement dans 'The Hammer of God'), sa conception artistique du réel, les limites instables et parfois ténues entre le bien et le mal, les représentations très esthétisées du crime exercent sur le lecteur un pouvoir de séduction tenace (et pernicieux ?) que l'on peut, en fin de compte, considérer comme une bizarrerie de l'ordre du « sucre dans la salière »...

\section{NOTES}

1. 'The Blue Cross' ouvre le recueil The Innocence of Father Brown (1911), dont les douze nouvelles, avant d'être publiées en volume en 1911, parurent dans des revues en 1910. Chesterton écrivit quatre autre recueils mettant en scène le père Brown: The Wisdom of Father Brown (1914), The Incredulity of Father Brown (1926), The Secret of Father Brown (1927) et The Scandal of Father Brown (1935).

2. Le corpus se fondera surtout sur cinq des nouvelles de ce recueil : 'The Blue Cross', 'The Queer Feet', 'The Flying Stars', 'The Invisible Man' et 'The Hammer of God'. Pour des raisons de brièveté, elles seront désignées respectivement par $\mathrm{BC}, \mathrm{QF}, \mathrm{FS}$, IM et HG. L'édition de référence sera The Complete Father Brown, London: Penguin Books, 1981.

3. Dans 'The Great Detectives: G. K. Chesterton. Father Brown', John PETERSON remarque : ' Chesterton was also the first respected literary critic to write extensively on the subject of the detective story. He read these stories himself, literally by the hundreds' (Strand Magazine, issue 3, copyright 2003-2006, <http://www.strandmag.com/fatherbrown> [dernière consultation le 25 mai 2012]).

4. BC, pp. 10-11.

5. IM, pp. 72-73.

6. Ibid., p. 73.

7. Ibid., p. 76.

8. Sa position est très révélatrice: 'The unimportant Father Brown [...] stood back, looking modestly at the pavement' (p. 74).

9. Chesterton partageait visiblement avec Arthur Conan DOYLE un goût prononcé pour l'étrange et pour les paradoxes. Au début de la nouvelle 'A Case of Identity', Holmes déclare : 'Life is infinitely stranger than anything which the mind of man could invent' (The Adventures of Sherlock Holmes, London: Penguin Books, 1994, p. 55). Les termes que Chesterton emploie dans sa dédicace de 1927 au père John O' Connor font écho à la vision de Holmes.

10. M. RIBSTEIN, G. K. Chesterton. Création littéraire et imagination, Paris : Éditions Klincksieck, 1981, p. 120. La création littéraire du père Brown préexiste donc largement à la conversion au catholicisme de Chesterton en 1922.

11. The Autobiography of G. K. Chesterton, New York: Sheed \& Ward, 1936, p. 336.

12. Ibid., pp. 333-334.

Revue Française de Civilisation Britannique, XVIII-1 | 2013 
13. Christiane D'HAUSSY, La Vision du monde chez G. K. Chesterton, Paris : Didier-Érudition (Études anglaises, 77), 1981, p. 243. De même : «Dans un schéma idéal, l'homme se fait très petit pour célébrer le bien et le beau, présents de Dieu » (Ibid., p. 244).

14. QF, p. 51.

15. Autobiography, p. 355.

16. QF, p. 50.

17. D'HAUSSY, op. cit., p. 237.

18. En catholique convaincu, il critique par exemple l'approche religieuse du forgeron presbytérien, qu'il considère comme l'héritier d'un paganisme écossais ancien et comme un homme prosaïque, trop ancré dans la terre : "Look at that blacksmith, for instance," went on Father Brown calmly; "a good man, but not a Christian - hard, imperious, unforgiving. Well, his Scotch religion was made up by men who prayed on hills and high crags, and learnt to look down on the world more than to look up at heaven." (HG, p. 129)

19. QF, p. 44.

20. Ibid., p. 39.

21. Mais Flambeau, voleur récidiviste à grande échelle, n'est pas un meurtrier, ce qui rend sa conversion plus plausible, et cela d'autant plus que, étant français, il est sans doute de culture catholique. Il est par ailleurs d'origine gasconne, d'une stature aussi colossale que son envergure dans le monde du crime, ce qui lui confère une dimension pittoresque, somme toute assez sympathique, séduisante et divertissante.

22. FS, pp. 63-64.

23. IM, p. 76.

24. QF, p. 53.

25. IM, p. 77.

26. "L'auteur, tout en éprouvant cette fascination pour l'horrible et l'obscur, s'efforce souvent d'y résister sans s'interroger, au moins publiquement, sur les raisons de son attirance pour cette zone d'ombre en lui » (D'HAUSSY, op. cit., p. 235) ; « Son inconscient a pris sa revanche en se manifestant par ces résurgences sataniques [...] Toute sa vie, il est épouvanté par les abîmes potentiels ou réels qu'il découvre ou qu'il imagine en lui-même. "Abîme » convient bien, car c'est en termes d'espace qu'il traduit le vertige spirituel que provoque en lui la contemplation des sombres précipices de son âme. » (Ibid., p. 236)

27. "Chesterton pense que le bien et le mal ont une densité et une existence réelles, mais il arrive qu'ils soient si étroitement associés qu'il n'est pas aisé de les distinguer l'un de l'autre. » (Ibid., p. 238)

28. Le père Brown se comporte ici comme le fait à l'occasion Sherlock Holmes, qui tait parfois l'identité du coupable et le laisse libre : “But hear me further. I say I know all this; but no one else shall know it. The next step is for you; I shall take no more steps; I will seal this with the seal of confession [...] you have not yet gone very far wrong, as assassins go. You did not help to fix the crime on the smith when it was easy; or on his wife, when that was easy. You tried to fix it on the imbecile because you knew that he could not suffer. That was one of the gleams that it is my business to find in assassins. And now come down into the village, and go your own way as free as the wind; for I have said my last word".' (HG, p. 131)

29. Ibid., p. 130 ; c'est moi qui souligne.

30. FS, p. 54.

31. QF, p. 51.

32. Le descriptif occupe une place prépondérante dans les Father Brown Stories, dont l'écriture est extrêmement travaillée et complexe, fait atypique pour des nouvelles de détection, où l'intrigue et l'action priment généralement. Comme le souligne Max Ribstein: "Mais l'un des aspects les plus originaux de ces histoires (en dehors du protagoniste), et des moins soulignés, est, selon nous, l'importance donnée au décor et à l'atmosphère, lesquels ne sont pas - ou pas seulement - un cadre, mais une réalité inquiétante pénétrée par la présence du mal. Au fond, les Father Brown Stories sont moins des histoires policières que de la théologie vécue personnellement et dramatisée sous forme littéraire [...] Chesterton a un 
côté nettement onirique et fantastique [...] Il semble éprouver une véritablement fascination pour la nuit et les périodes aurorales et crépusculaires » (RIBSTEIN, op. cit., p. 141).

33. BC, p. 18.

34. HG, p. 128.

35. Ibid., p. 121.

36. 'The Mirror of the Magistrate', in Secret of Father Brown, p. 471.

37. La signification et la fonction du thème théâtral et de ses diverses mises en œuvre (littérales, comme la pantomime de FS, ou plus métaphoriques, comme dans QF, p. 44) dépassent largement le sens univoque et orthodoxe que leur prête Max Ribstein, selon lequel : "Le théâtre est partout présent dans les Father Brown Stories [...] Nous rejoignons là l'idée que Satan est le grand illusionniste, Diabolus Simius Dei. Satan se sert de la puissance trompeuse qu'est l'imagination; Chesterton veut montrer que l'homme sans Dieu vit dans un imaginaire factice et dangereux. » (p. 142) Mais Chesterton comme le père Brown cèdent à l'évidence à la fascination de cet «imaginaire factice et dangereux ».

38. FS, p. 57.

39. BC, p. 19

40. FS., p. 54.

41. D'HAUSSY, op. cit., p. 241.

42. BC, pp. 15-16; c'est moi qui souligne.

43. HG, p. 129.

44. Ibid., p. 130 ; c'est moi qui souligne.

45. BC, p. 21.

46. HG, p. 130.

47. 'It was a curious experience to find that this quiet and pleasant celibate had plumbed those abysses far deeper than I. I had not imagined that the world could hold such horrors.' (Autobiography, pp. 337-338) La réaction de Flambeau est directement inspirée de celle de l'auteur à la fin de 'The Blue Cross' : 'How in blazes do you know all these horrors?' (p. 23)

\section{RÉSUMÉS}

Que Chesterton ait choisi le père Brown, un prêtre catholique, comme détective amateur de ses nouvelles n'a rien d'orthodoxe, et les portraits peu flatteurs qui en sont brossés le sont encore moins, même si, au bout du compte, le personnage (inspiré d'un modèle réel) est un être d'exception qui incarne et exprime les valeurs chrétiennes de son auteur. Mais en dépit du message orthodoxe explicite, une forme insidieuse et subliminale d'hétérodoxie imprègne la représentation du crime, très esthétisée, et brouille les frontières entre le bien et le mal.

Chesterton's choice of Father Brown, a Catholic priest, as the amateur detective of his short stories is not an orthodox one and the unflattering way in which he is portrayed is still less so, although the priest, inspired from a real-life model, turns out to be peerless. He embodies and voices the Christian values shared by his author. But despite the explicit orthodox message, an insidious, subliminal form of heterodoxy filters through: the representation of crime is highly aesthetic and the borderline between good and evil, sometimes blurred. 
AUTEUR

FRANÇOISE DUPEYRON-LAFAY

Université Paris-Est Créteil 